\title{
ANALISIS KOMPETENSI PEDAGOGIK GURU SD DI UPTD PENDIDIKAN BANYUMANIK KOTA SEMARANG
}

\author{
c.6r. D. \\ Muhamad Afandi \\ Universitas Islam Sultan Agung, Semarang, Indonesia \\ mafandi@unissula.ac.id
}

Sri Wahyuningsih

IAINKudus, Indonesia

wahyuningsih@stainkudus.ac.id

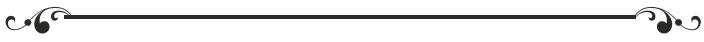

\begin{abstract}
PEDAGOGIC COMPETENCIES ANALYSIS OF ELEMENTARY SCHOOL TEACHERS AT UPTD BANYUMANIK SEMARANG CITY. The purpose of this study was to describe the teachers' pedagogic competencies of elementary schools in Banyumanik Education UPTD Semarang City. This study used a quantitative descriptive method with samples 162 elementary school teachers selected by random sampling technique. The instruments used were assessment sheets consisting of 50 statement items, and 10 indicators. The results showed that the indicator of the ability of teachers to master the characteristics of students is good (81.8\%), the ability of teachers to master learning theory and the principles of learning is good (77.1\%), the ability of teachers to develop curriculum related to subjects/fields taught is good (82\%), the ability of teachers to carry out educating learning is good (85.2\%), the ability of teachers to use information and communication technology for the benefit of learning is good (77.6\%), the ability of teachers in facilitating the development of potential students to actualize various potential owned is good (84.6\%). Overall pedagogic competence of elementary school teachers in Banyumanik Education UPTD is good (81.3\%).
\end{abstract}

Keywords: pedagogic competencies, Elementary School teachers, Banyumanik Education UPTD 


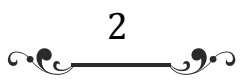

\begin{abstract}
Abstrak
Tujuan penelitian ini adalah untuk mendeskripsikan kompetensi pedagogikguru Sekolah Dasar di UPTD Pendidikan Banyumanik Kota Semarang.Penelitian ini menggunakan metode deskriptif kuantitatif dengansampel sebanyak 162 guru SD yang dipilih dengan teknik random sampling.Intrumen yang digunakan adalah lembar penilaian yang terdiri dari 50 item pernyataan, dan 10 indikator. Hasil penelitian menunjukkan bahwa pada indikator kemampuan guru menguasai karakteristik peserta didik adalah baik (81.8\%), kemampuan guru menguasai teori belajar dan prinsip-prinsip pembelajaran yang mendidik adalah baik $(77.1 \%)$, kemampuan guru mengembangkan kurikulum terkait dengan mata pelajaran/bidang pengembangan yang diampu adalah baik (82\%), kemampuan guru menyelenggarakan pembelajaran yang mendidik adalah baik (85.2\%), kemampuan guru memanfaatkan teknologi informasi dan komunikasi untuk kepentingan pembelajaran adalah baik (77.6\%), kemampuan guru memfasilitasi pengembangan potensi peserta didik untuk mengaktualisasikan berbagai potensi yang dimiliki adalah baik (84.6\%). Secara keseluruhan kompetensi pedagogik guru Sekolah Dasar di UPTD Pendidikan Banyumanik adalah baik $(81,3 \%)$.
\end{abstract}

Kata Kunci: kompetensi pedagogik, guru Sekolah Dasar, UPTD pendidikan Banyumanik

\title{
A. Pendahuluan
}

Undang-undang Nomor 14 tahun 2005 tentang Guru dan Dosen, pada pasal 1 dijelaskan bahwa guru adalah pendidik profesional dengan tugas utama mendidik, mengajar, membimbing, mengarahkan, melatih, menilai, dan mengevaluasi peserta didik pada pendidikan anak usia dini jalur pendidikan formal, pendidikan dasar, dan pendidikan menengah. Dalam Undang-undang guru dan dosen, guru diharapkan memiliki kompetensi dalam bidang pengetahuan, keterampilan, dan perilaku.Hal tersebut sebaiknya diimpelementasikan dalam melaksanakan tugas keprofesionalannya.Pendidikan menjadi salah satu sarana pembangunan yang selalu ditingkatkan, baik kualitas maupun kuantitasnya.Hal ini sangat diperlukan dalam mengupayakan 


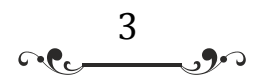

pembaharuan dan penyempurnaan pendidikan serta menciptakan sumber daya manusia yang berkualitas.Pendidikan sangat penting sehingga tidak dapat dipisahkan dari kehidupan.Berkembangnya suatu negara banyak ditentukan oleh perkembangan kualitas pendidikan pada negara tersebut.

Menurut Zakaria (2017) guru merupakan ujung tombak dalam pelaksanaan program-program pendidikan di sekolah.Oleh karena itu, tidak ada yang meragukan, betapa pentingnya peran guru bagi keberhasilan upaya peningkatan dan pemerataan mutu pendidikan di sekolah.Dalam hal ini guru wajib memiliki kualifikasi akademik, kompetensi, sertifikat pendidik, sehat jasmani dan rohani, serta memiliki kemampuan untuk mewujudkan tujuan pendidikan nasional.Lebih dari itu, guru merupakan pendidik profesional dengan tugas utama mendidik, mengajar, membimbing, mengarahkan, melatih, menilai dan mengevaluasi peserta didik. Sementara kinerja guru dimaknai prestasi yang dicapai oleh seseorang guru dalam melaksanakan tugasnya selama periode waktu tertentu yang diukur berdasarkan tiga indicator, yaitu: (1) penguasaan bahan ajar, (2) kemampuan mengelola pembelajaran dan (3) komitmen menjalankan tugas.

Dalam melaksanakan tugasnya guru diharapkan memilki kompetensi pedagogik, berdasarkan konferensi pers akhir tahun 2015 di Kantor Kemendikbud yang dilakukan oleh Direktur Jenderal Guru dan Tenaga Kependidikan Kementerian Pendidikan dan Kebudayaan, Surapranata, S. (2016) mengatakan, jika dirinci hasil UKG untuk kompetensi bidang pedagogik saja, rata-rata nasionalnya hanya 48,94, yakni berada di bawah standar kompetensi minimal (SKM), yaitu 55. Bahkan untuk bidang pedagogik ini, hanya ada satu provinsi yang nilainya di atas rata-rata nasional sekaligus mencapai SKM, yaitu Yogyakarta sebesar 56,91. Hal ini berarti kompetensi pedagogik setiap guru harus diperhatikan dan ditingkatkan.

Kompetensi Pedagogik mencakup pengetahuan yang baik, luas dan mendalam tentang subjek atau materi pembelajaran.Seorang guru pedagogis harus menunjukkan kemampuan yang baik dalam menggunakan dan menerapkan pengetahuan baik bersifat praktis maupun tindakan pedagogis dengan memfokuskan siswa belajar. Pendapat senada dijelaskan 


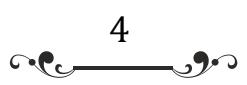

Apelgren \& Giertz dalam Olatunji, M. O. (2013: 75) yang mendefinisikan kompetensi pedagogik sebagai kemampuan dan kemauan secara teratur untuk menerapkan sikap, pengetahuan, dan keterampilan yang mengutamakan belajar siswa dengan cara terbaik. Cara tersebut harus sesuai dengan tujuan yang berlaku dan berdasarkan peningkatan berkelanjutan kompetensi guru sendiri dan desain instruksional.Ada beberapa aspek penting dalam kompetensi pedagogik guru. Aspek-aspek tersebut meliputi pengetahuan, kemampuan, sikap, beradaptasi dengan situasi, Ketekunan, dan peningkatan berkelanjutan.

Dalam Standar Nasional Pendidikan pasal 28 ayat (3) butir a dijelaskan bahwa kompetensi pedagogik adalah kemampuan mengelaola pembelajaran peserta didik yang meliputi pemahman terhadap peserta didik, perancangana dan pelaksanaan pembelajaran, evaluasi hasil belajar dan pengembanagn peserta didik untuk mengaktualisasikan berbagai potensi yang dimilikinya. Oleh karenanya, kompetensi pedagogik merupakan aspek penting pada kegiatan mengajar dan mendidik serta sebagai dasar atau fundamental bagi guru dalam melaksanakan tugas profesionalnya, terutama tugas mendidik, mengajar, membimbing, mengarahkan, melatih, menilai dan mengevaluasi peserta didik.Dengan demikian terlihat jelas bahwa kompetensi pedagogik guru merupakan faktor utama yang menentukan keberhasilan kualitas pembelajaran di Sekolah Dasar.

Beberapa penelitian tentang kompetensi pedagogik telah dilakukan oleh para peneliti sebelumnya.Akhyak., dkk. (2013: 1) mendeskripsikan tentang implementasi kompetensi pedagogik guru untuk mengoptimalkan siswa Sekolah Dasar di Indonesia.Pada penelitiannya, ada tiga lokasi yang menjadi tempat penelitiannya yaitu Sekolah Dasar di Yogyakarta, Sekolah Dasar di Tulung Agung, Jawa Timur dan Sekolah Dasar di Surabaya.Adapun metode yang digunakan adalah deskriptif kualitatif dengan teknik wawancara mendalam, observasi dan dokumentasi.Hasil menunjukkan bahwa untuk mengoptimalkan perkembangan peserta didik di Indonesia, guru harus memiliki usaha-usaha serius untuk mengembangkan intelektual, emosional dan moral peserta didik.Dalam hal ini kompetensi pedagogik wajib dimiliki oleh setiap guru di Indonesia. 


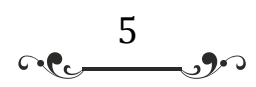

Selanjutnya Nicholas, S.O. \& Boadu, K. (2013) menjelaskan tentang persepsi mahasiswa terhadap inovasi kurikulum untuk meningkatkan kompetensi pedagogik dan ICT di Ghana. Hasil menunjukkan bahwa aspek pedagogik yang mencakup kerja sama, partisipasi kerja, evaluasi diri dan refleksi, fasilitas belajar, administrasi sekolah, manajemen kelas, manajemen kompetensi komunitas sekolah, dan metode pengajaran merupakan aspek penting yang harus dimiliki oleh responden. Dalam hal ini guru memiliki peran penting untuk menerapkan aspek pedagogik kepada peserta didiknya.

Penelitian selanjutnya dilakukan oleh Febrianis, I., dkk.(2014: 145) yang menawarkan pendekatan yang afektif dalam penetapan kebutuhan pelatihan guru dengan menggunakan metode Training Needs Assessment (TNA).Hasil penelitian menunjukkan bahwa tingkat kompetensi pedagogik aktual guru IPA SMP berada di bawah standar kompetensi ideal. Lima prioritas program pelatihan adalah pelatihan TIK/ICT, penelitian tindakan kelas (PTK), teori dan prinsip pembelajaran IPA terpadu, pengembangan kurikulum IPA terpadu, dan penguasaan karakteristik peserta didik. In House Training (IHT), pelatihan khusus, dan kursus singkat direkomendasikan sebagai metode pelatihan yang efektif untuk meningkatkan kompetensi pedagogik guru IPA SMP. Selanjutnya, Gewasari, M. (2016: 29) mendeskripsikan tentang pengaruh kompetensi guru, kepemimpinan kepala sekolah, budaya organisasi spiritual sekolah, kepuasan kerja, dan motivasi berprestasi terhadap kinerja guru SMA di Deli Serdang. Hasil menunjukkan bahwa kompetensi guru, kepemimpinan kepala sekolah, budaya organisasi, kepuasan kerja dan notivasi kerja berpengaruh siginifikan secara langsung dan tidak langsung terhadap kinerja guru di SMA Negeri Deli Serdang.

Sama halnya dengan penelitian-penelitian terdahulu, penelitian yang dikaji peneliti sekarang juga mendeskripsikan kompetensi pedagogik guru.Akan tetapi perbedaanya adalah penelitian yang dikaji peneliti lebih fokus pada analisis kompetensi pedagogik guru Sekolah Dasar Negeri di Unit Pelaksana Teknis Daerah (UPTD) Pendidikan Banyumanik Kota Semarang sebanyak 31 sekolah. 


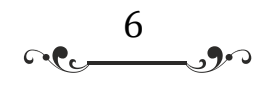

Metode penelitian yang digunakan adalah deskriptif kuantitatif.Tempat penelitian dilaksanakan di seluruh sekolah dasar negeri di UPTD Pendidikan Kec.Bayumanik Kota Semarang Jawa Tengah sebanyak 31 sekolah.Populasi adalah wilayah generalisasi yang terdiri atas objek-objek yang mempunyai kuantitas dan karatersitik tertentu yang ditetapkan oleh peneliti untuk dipelajari dan kemudian ditarik kesimpulan (Sugiyono, 2016: 117).Populasi dalam penelitian ini adalah guru-guru Sekolah Dasar Negeri UPTD Pendidikan Banyumanik Kota Semarang, dengan jumlah sekolah sebanyak 7Kelompok Kerja Guru/ Gugus, guru kelas keseluruhannya sebanyak 272 orang.Dalam penelitian ini teknik pengambilan sampel dilakukan dengan menggunakan teknik simple random sampling of area dengan penetapan responden sampelnya secara undian.Adapun sampel yang didapat dalam penelitian ini sebanyak 162 orang guru. Teknik pengambilan sampel dengan cara random setiap Gugus UPTD Pendidikan Kecamatan Banyumanik Kota Semarang. Penentuan guru diundi berdasarkan Kelompok Kerja Guru/ Gugus kemudian guru dimasing-masing sekolah dirandom sampling dengan alasan agar setiap sekolah dan guru masing-masing sekolah mendapatkan kesempatan yang sama sebagai sampel. Untuk instrumen kompetensi pedagogik sekolah dasar diisi oleh guru.

Pengumpulan data penelitian ini dilakukan dengan menggunakan angket. Angket atau (questionnaire) merupakan suatu teknik atau cara mengumpulkan data secara tidak langsung (peneliti tidak langsung bertanya jawab dengan responden). Instrumen angket berisi sejumlah pertanyaan atau pernyataan yang harus dijawab atau direspon oleh responden (Sukmadinata, 2013: 219).Untuk menjaring informasi atau data dari responden disusun instrumen penelitian.Intrumen angketdibuat berpedoman pada konsepsional yang meliputi definisi konseptual, definisi operasional, dan kisi-kisi instrumen penelitian, kalibrasi instrument, Pengujian Validitas dan Realiabilitas.Jumlah pernyataan memilki empat alternatif jawaban. Skala pengukuran intrumen angket dibuat berdasarkan skala Likert dengan empat alternatif jawaban yaitu: (1) Selalu dengan skor 4, (2) Sering dengan skor 3, (3) Kadang-kadang dengan skor 2, (4) Tidak pernah dengan skor 1. 


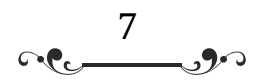

Data penelitian terkumpul, dianalisis secara deskriptif dengan kriteria sesuai permenpan \& RB 2009 pasal 15 sebagai berikut: nilai 91 sampai dengan 100 disebut amat baik; b. nilai 76 sampai dengan 90 disebut baik; c. nilai 61 sampai dengan 75 disebut cukup; d. nilai 51 sampai dengan 60 disebut sedang; dan e. nilai sampai dengan 50 disebut kurang.

\section{B. Pembahasan}

\section{Kemampuan Guru Dalam Menguasai Karakteristik Peserta Didik}

Pemahaman terhadap peserta didik merupakan aspek penting dalam kompetensi pedagogik setiap guru. Dalam hal ini guru diharapkan mampu menggunakan informasi tentang hal-hal berkaitan karakteristik peserta didik dengan tujuan untuk membantu mereka dalam proses pembelajaran. Pemahaman karakteristik peserta didik meliputi berbagai aspek diantaranya aspek fisik, intelektual, sosial, emosional, moral dan latar belakang sosial budaya.Berdasarkan analisis data, kemampuan guru Sekolah Dasar Negeri di Unit Pelaksana Teknis Daerah (UPTD) Pendidikan Banyumanik dapat disajikan pada Tabel 1.

Tabel 1.Kemampuan Guru Menguasai Karakteristik Peserta Didik

\begin{tabular}{|l|l|l|l|}
\hline No & \multicolumn{1}{|c|}{ Item Pernyataan } & \% & Kriteria \\
\hline 1 & $\begin{array}{l}\text { Memahami karakteristik peserta didik } \\
\text { usia sekolah dasar }\end{array}$ & 80.6 & Baik \\
\hline 2 & $\begin{array}{l}\text { Mengidentifikasi potensi peserta didik } \\
\text { usia sekolah dasar dalam lima mata } \\
\text { pelajaran SD }\end{array}$ & 81.6 & Baik \\
\hline 3 & $\begin{array}{l}\text { Mengidentifikasi kemampuan awal } \\
\text { peserta didik usia sekolah dasar } \\
\text { dalam lima mata pelajaran SD. }\end{array}$ & 81.3 & Baik \\
\hline 4 & $\begin{array}{l}\text { Mengidentifikasi kesulitan peserta } \\
\text { belajar usia sekolah dasar dalam lima } \\
\text { mata pelajaran SD. }\end{array}$ & 83.6 & Baik \\
\hline & Total & 81.8 & Baik \\
\hline
\end{tabular}




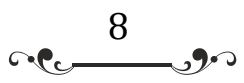

Rerata skor kemampuan guru Sekolah Dasar Negeri di Unit Pelaksana Teknis Daerah (UPTD) Pendidikan Banyumanik kota Semarang dalam menguasai karakteristik peserta didik berada pada kriteria baik (Tabel 1). Adapun rerata tertinggi terdapat pada item pernyataan mengidentifikasi kesulitan peserta belajar usia sekolah dasar dalam lima mata pelajaran SD. Tabel 1 menunjukkan guru-guru SD di Unit Pelaksana Teknis Daerah (UPTD) Pendidikan Banyumanik kota Semarang dapat dikatakan mampu dalam memahami karakter peserta didiknya. Hal ini sejalan dengan Jaedun, A. (2009: 9) yang menjelaskan kemampuan guru dalam memahami peserta didik merupakan aspek substantif dalam kompetensi didik.Oleh karenanya, setiap guru selayaknya mampu memahami kondisi peserta didik dalam berbagai hal.

\section{Kemampuan Guru dalam Menguasai Teori Belajar dan Prinsip-Prinsip Pembelajaran yang Mendidik}

Kemampuan guru dalam menguasai teori belajar dan prinsipprinsip pembelajaran yang mendidik merupakan aspek penting dalam hal perencanaan dan pelaksanaan pembelajaran.Berdasarkan analisis data, kemampuan menguasai teori belajar dan prinsipprinsip pembelajaran yang mendidik guru Sekolah Dasar UPTD Pendidikan Banyumanik Kota Semarang dapat disajikan pada Tabel 2.

Tabel 2.Kemampuan Menguasai Teori Belajar dan Prinsip-Prinsip Pembelajaran Yang Mendidik

\begin{tabular}{|l|l|c|c|}
\hline No & \multicolumn{1}{|c|}{ Sub Indikator } & \% & Kriteria \\
\hline 1 & $\begin{array}{l}\text { Memahami berbagai teori belajar dan } \\
\text { prinsip-prinsip pembelajaran yang } \\
\text { mendidik terkait dengan lima mata } \\
\text { pelajaran SD. }\end{array}$ & Cukup Baik \\
\hline 2 & $\begin{array}{l}\text { Menerapkan berbagai pendekatan, } \\
\text { strategi, metode, dan teknik } \\
\text { pembelajaran yang mendidik secara } \\
\text { kreatif dalam lima mata pelajaran SD. }\end{array}$ & Baik & \\
\hline & Total & 77.1 & Baik \\
\hline
\end{tabular}




$$
\text { recers }
$$

Tabel 2. menunjukkan bahwa Rerata kemampuan guru SD di UPTD Pendidikan Banyumanik kota Semarang dalam menguasai teori belajar dan prinsip-prinsip pembelajaran yang mendidik berada pada kriteria baik terutama pada sub indikator menerapkan berbagai pendekatan, strategi, metode dan teknik pembelajaran yang mendidik secara kreatif dalam lima mata pelajaran SD. Adapun sub indikator guru memahami berbagai teori belajar dan prinsip-prinsip pembelajaran yang mendidik terkait dengan lima mata pelajaran SD perlu dikembangkan agar proses pembelajaran dapat berjalan dengan maksimal.

\section{Kemampuan Guru Dalam Mengembangkan Kurikulum yang Terkait dengan Mata Pelajaran/Bidang Pengembangan.}

Kemampuan guru dalam mengembangkan kurikulum terkait dengan mata pelajaran yang diampu merupakan bagian dari kompetensi pedagogi dalam hal merencanakan dan melaksanakan proses pembelajaran. Berdasarkan analisis data, didapatkan kemampuan guru SDN di UPTD Pendidikan Banyumanik kota Semarang dalam mengembangkan kurikulum yang terkait dengan mata pelajaran/bidang pengembangan yang disajikan pada Tabel 3.

Tabel 3. Kemampuan Guru dalamMengembangkan Kurikulum yang Terkait dengan Mata Pelajaran/Bidang Pengembangan yang Diampu.

\begin{tabular}{|c|l|c|l|}
\hline No & \multicolumn{1}{|c|}{ Item Pernyataan } & $\%$ & Kriteria \\
\hline 1 & $\begin{array}{l}\text { Memahami prinsip-prinsip } \\
\text { pengembangan kurikulum. }\end{array}$ & 75.8 & Baik \\
\hline 2 & $\begin{array}{l}\text { Menentukan tujuan lima mata } \\
\text { pelajaran SD }\end{array}$ & 79.7 & Baik \\
\hline 3 & $\begin{array}{l}\text { Menentukan pengalaman belajar } \\
\text { yang sesuai untuk mencapai tujuan } \\
\text { lima mata pelajaran SD. }\end{array}$ & Baik \\
\hline 4 & $\begin{array}{l}\text { Memilih materi lima mata } \\
\text { pelajaran SD yang terkait dengan } \\
\text { pengalaman belajar dan tujuan } \\
\text { pembelajaran. }\end{array}$ & Baik \\
\hline
\end{tabular}


recus

\begin{tabular}{|c|l|l|l|l|}
\hline 5 & $\begin{array}{l}\text { Menata materi pembelajaran } \\
\text { secara benar sesuai dengan } \\
\text { pendekatan yang dipilih dan } \\
\text { karakteristik peserta didik usia SD }\end{array}$ & Baik \\
\hline 6 & $\begin{array}{l}\text { Mengembangkan indikator dan } \\
\text { instrumen penilaian }\end{array}$ & 81.2 & Baik \\
\hline & Total & 82 & Baik \\
\hline
\end{tabular}

Rerata skor kemampuan guru mengembangkan kurikulum yang terkait dengan mata pelajaran/bidang pengembangan yang diampu berada pada kriteria baik (Tabel 3).Rerata tertinggi terdapat pada pernyataan manata materi pembelajaran secara benar dan sesuai dengan pendekatan yang dipilih dan karakteristik peserta didik.Rerata terendah terdapat pada pernyataan memahami prinsipprinsip pengembangan kurikulum. Hal ini berarti kemampuan guru SD di UPTD Pendidikan Banyumanik Kota Semarang perlu ditingkatkan lagi melalui berbagai cara diantaranya dengan aktif mengikuti pelatihan atau seminar tentang pengembangan kurikulum dan memperbanyak referensi terkait kurikulum pendidikan Sekolah Dasar.

\section{Kemampuan Guru dalam Menyelenggarakan Pembelajaran yang Mendidik.}

Kemampuan menyelenggarakan pembelajaran yang mendidik merupakan aspek inti dalam kompetensi pedagogik. Berdasarkan analisis data, didapatkan kemampuan guru Sekolah Dasar di UPTD pendidikan Banyumanik kota Semarang dalam menyelenggarakan pembelajaran yang mendidik yang disajikan pada Tabel 4.

Tabel 4.Menyelenggarakan pembelajaran yang mendidik.

\begin{tabular}{|l|lr|l|l|}
\hline No & Item Pernyataan & \% & Kriteria \\
\hline 1 & $\begin{array}{l}\text { Memahami prinsip-prinsip } \\
\text { perancangan pembelajaran yang } \\
\text { mendidik. }\end{array}$ & Baik \\
\hline 2 & \multicolumn{2}{l|}{ Mengembangkan komponen- } & 86 & Baik \\
\hline
\end{tabular}


recus

\begin{tabular}{|l|l|l|l|}
\hline & $\begin{array}{l}\text { komponen rancangan } \\
\text { pembelajaran. }\end{array}$ & & \\
\hline 3 & $\begin{array}{l}\text { Menyusun rancangan } \\
\text { pembelajaran yang lengkap untuk } \\
\text { kegiatan pembelajaran. }\end{array}$ & 84.7 & Baik \\
\hline 4 & $\begin{array}{l}\text { Melaksanakan pembelajaran yang } \\
\text { mendidik di kelas. }\end{array}$ & 85.5 & Baik \\
\hline 5 & $\begin{array}{l}\text { Menggunakan media pembelajaran } \\
\text { sesuai dengan karakteristik } \\
\text { peserta didik dan lima mata } \\
\text { pelajaran SD untuk mencapai } \\
\text { tujuan pembelajaran secara utuh }\end{array}$ & Baik \\
\hline 6 & $\begin{array}{l}\text { Mengambil keputusan } \\
\text { transaksional dalam lima mata } \\
\text { pelajaran SD sesuai dengan situasi } \\
\text { yang berkembang. }\end{array}$ & Baik \\
\hline & Total & 85.2 & Baik \\
\hline
\end{tabular}

Rerata skor guru SD di UPTD Pendidikan Banyumanik Kota Semarang berada pada kriteria baik (Tabel 4). Akan tetapi rerata terendah terdapat pada item pernyataan menggunakan media pembelajaran sesuai dengan karakteristik peserta didik dan lima mata pelajaran SD untuk mencapai tujuan pembelajaran yang utuh. Hal ini menunjukkan bahwa guru-guru SD diharapkan lebih meningkatkan kreativitas dalam menggunakan media pembelajaran agar siswa lebih tertarik dalam mengikuti proses pembelajaran.

\section{Kemampuan Memanfaatkan Teknologi Informasi dan Komunikasi untuk Kepentingan Pembelajaran.}

Teknologi informasi dan komunikasi untuk kepentingan pembelajaran merupakan sarana penunjang dalam proses pembelajaran di kelas. Berdasarkan analisis data, didapatkan kemampuan guru SD di UPTD pendidikan Banyumanik Kota Semarang dalam memanfaatkan teknologi informasi dan komunikasi untuk kepentingan pembelajaran yang disajikan pada Tabel 5 . 


$$
\text { r.c. }
$$

Tabel 5.KemampuanMemanfaatkan teknologi informasi dan komunikasi untuk kepentingan pembelajaran

\begin{tabular}{|c|c|c|c|}
\hline No & Item Pernyataan & $\%$ & Kriteria \\
\hline 1 & $\begin{array}{l}\text { Memanfaatkan teknologi informasi } \\
\text { dan komunikasi dalam } \\
\text { pembelajaran. }\end{array}$ & 77.6 & Baik \\
\hline & Total & $.6^{77}$ & Baik \\
\hline
\end{tabular}

Rerata skor kemampuan guru dalam memanfaatkan teknologi dan komunikasi untuk kepentingan pembelajaran berada pada kriteria baik (Tabel 5).Hal ini sejalan dengan pernyataan Yaumi, M. (2011) bahwa penggunaan media komunikasi seperti internet telah membangun model interaksi baru dalam pembelajaran pada saat sekarang ini.

\section{Kemampuan Memfasilitasi Pengembangan Potensi Peserta Didik untuk Mengaktualisasikan Berbagai Potensi yang Dimiliki}

Berdasarkan analisis data, didapatkan kemampuan guru-guru Sekolah Dasar di UPTD Pendidikan Banyumanik Kota Semarang dalam memfasilitasi pengembangan potensi peserta didik untuk mengaktualisasikan berbagai potensi yang dimiliki yang disajikan pada Tabel 6 .

Tabel 6.KemampuanMemfasilitasi pengembangan potensi peserta didik untuk mengaktualisasikan berbagai potensi yang dimiliki.

\begin{tabular}{|l|l|l|l|}
\hline No & Sub Indikator & \% & Kriteria \\
\hline 1 & $\begin{array}{l}\text { Menyediakan berbagai kegiatan } \\
\text { pembelajaran untuk mendorong peserta } \\
\text { didik mencapai prestasi belajar secara } \\
\text { optimal. }\end{array}$ & Baik \\
\hline 2 & $\begin{array}{l}\text { Menyediakan berbagai kegiatan } \\
\text { pembelajaran untuk mengaktualisasikan } \\
\text { potensi peserta didik, termasuk } \\
\text { kreativitasnya }\end{array}$ & & \\
\hline & Botal & 82.9 & Baik \\
\hline
\end{tabular}




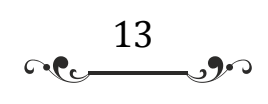

Rerata skor kemampuan guru dalam memfasilitasi pengembangan potensi peserta didik untuk mengaktualisasikan berbagai potensi yang dimiliki berada pada kriteria baik (Tabel 6).Hal ini menunjukkan bahwa para guru Sekolah Dasar di UPTD Pendidikan Banyumanik Kota Semarang telah berusaha secara maksimal dalam mengembangkan potensi peserta didik.

7. Kemampuan Berkomunikasi Secara Efektif, Empatik, dan Santun dengan Peserta Didik

Berdasarkan analisis data, didapatkan hasil kemampuan guru Sekolah Dasar di UPTD Pendidikan Banyumanik Kota Semarang dalam berkomunikasi secara efektif, empatik, dan santun dengan peserta yang disajikan pada Tabel 7.

Tabel 7.Kemampuan Berkomunikasi Secara Efektif, Empatik, dan Santun dengan Peserta Didik.

\begin{tabular}{|l|l|l|l|}
\hline No & Sub Indikator strategi & $\mathbf{\%}$ & Kriteria \\
\hline 1 & $\begin{array}{l}\text { Memahami berbagai erik } \\
\text { berkomunikasi yang efektif, empatik dan } \\
\text { santun, baik secara lisan maupun tulisan }\end{array}$ & 87 & Baik \\
\hline 2 & $\begin{array}{l}\text { Berkomunikasi secara efektif, empatik, dan } \\
\text { santun dengan peserta didik }\end{array}$ & 88.6 & Baik \\
\hline & Total & 87.8 & Baik \\
\hline
\end{tabular}

Rerata skor pada kemampuan berkomunikasi guru secara efektif, empatik dan santun dengan peserta didik oleh guru-guru SD di UPTD Pendidikan Banyumanik Kota Semarang berada pada kriteria baik (Tabel 7).Hal ini menunjukkan bahwa guru-guru tersebut telah mampu menjadi teladan bagi peserta didik terutama pada hal berkomunikasi secara emaptik dan santun.

\section{Kemampuan Menyelenggarakan Penilaian Proses dan Hasil Belajar.}

Disamping merancang dan melaksanakan pembelajaran, guru juga dituntut untuk mampu mampu menyelenggarakan penilaian proses dan hasil belajar sebagai bentuk evaluasi pembelajaran. 


$$
\text { r.e. } 14
$$

Berdasarkan analisis data, kemampuan guru SD di UPTD pendidikan Banyumanik dalam menyelenggarakan penilaian proses dan hasil belajar dapat disajikan pada Tabel 8 .

Tabel 8. KemampuanMenyelenggarakan Penilaian Proses dan Hasil Belajar.

\begin{tabular}{|c|c|c|c|}
\hline No & Item Pernyataan & $\%$ & Kriteria \\
\hline 1 & $\begin{array}{l}\text { Memahami prinsip-prinsip penilaian } \\
\text { dan evaluasi proses dan hasil belajar } \\
\text { sesuai dengan karakteristik lima } \\
\text { mata pelajaran SD }\end{array}$ & 81.3 & Baik \\
\hline 2 & $\begin{array}{l}\text { Menentukan aspek-aspek proses } \\
\text { dan hasil belajar yang penting untuk } \\
\text { dinilai dan dievaluasi sesuai dengan } \\
\text { karakteristik lima mata pelajaran } \\
\text { SD. }\end{array}$ & 83.3 & Baik \\
\hline 3 & $\begin{array}{l}\text { Menentukan prosedur penilaian dan } \\
\text { evaluasi proses dan hasil belajar. }\end{array}$ & 81.3 & Baik \\
\hline 4 & $\begin{array}{l}\text { Mengembangkan instrumen } \\
\text { penilaian dan evaluasi proses dan } \\
\text { hasil belajar. }\end{array}$ & 76.5 & Baik \\
\hline 5 & $\begin{array}{l}\text { Mengadministrasikan penilaian } \\
\text { proses dan hasil belajar secara } \\
\text { berkesinambungan } \\
\text { mengunakan berbagai instrumen. }\end{array}$ & 80.7 & Baik \\
\hline 6 & $\begin{array}{l}\text { Menganalisis hasil penilaian proses } \\
\text { dan hasil belajar untuk berbagai } \\
\text { tujuan. }\end{array}$ & 86 & Baik \\
\hline \multirow[t]{2}{*}{7} & $\begin{array}{l}\text { Melakukan evaluasi proses dan hasil } \\
\text { belajar }\end{array}$ & 85.5 & \\
\hline & Total & 82.1 & Baik \\
\hline
\end{tabular}

Rerata skor pada kemampuan guru SD di UPTD Pendidikan Banyumanik Kota Semarang dalam menyelenggarakan penilaian proses dan hasil belajar berada pada kriteria baik (Tabel 8). Rerata skor terendah terdapat pada item pernyataan mengembangkan 


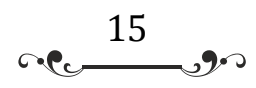

instrumen penilaian dan evaluasi proses dan hasil belajar. Hal ini menunjukkan bahwa kemampuan mengembangkan instrumen penilaian dan evaluasi proses dan hasil belajar para guru SD masik terbatas sehingga perlu ditingkatkan lagi dalam hal menyusun dan mengembangkan instrumen penilaian.

\section{Kemampuan Memanfaatkan Hasil Penilaian untuk Kepentingan Pembelajaran.}

Berdasarkan analisis data, kemampuan guru-guru SD di UPTD Pendidikan Banyumanik Kota Semarang dalam memanfaatkan hasil penilaian untuk kepentingan pembelajaran dapat disajikan pada Tabel 9.

Tabel 9. Kemampuan Memanfaatkan Hasil Penilaian untuk Kepentingan Pembelajaran.

\begin{tabular}{|l|l|l|l|}
\hline No & Item Pernyataan & $\mathbf{\%}$ & Kriteria \\
\hline 1 & $\begin{array}{l}\text { Menggunakan informasi hasil } \\
\text { penilaian dan evaluasi untuk } \\
\text { menentukan ketuntasan belajar. }\end{array}$ & 92 & Amat Baik \\
\hline 2 & $\begin{array}{l}\text { Menggunakan informasi hasil } \\
\text { penilaian dan evaluasi untuk } \\
\text { merancang program remedial dan } \\
\text { pengayaan. }\end{array}$ & $\begin{array}{l}\text { Baik } \\
\text { dan evaluasi kepada pemangku } \\
\text { kepentingan. }\end{array}$ & $\begin{array}{l}\text { Memanfaatkan informasi hasil } \\
\text { penilaian dan evaluasi pembelajaran } \\
\text { untuk meningkatkan kualitas } \\
\text { pembelajaran. }\end{array}$ \\
\hline Total p4.4 & Baik \\
\hline
\end{tabular}

Rerata skor kemampuan memanfaat hasil penilaian untuk kepentingan pembelajaran oleh guru-guru SD di UPTD Pendidikan Banyumanik berada pada kategori baik (Tabel 9).Adapun rerata skor tertinggi terdapat pada item pernyataan menggunakan informasi 


$$
\text { r.e. } 16
$$

hasil penilaian dan evaluasi untuk menentukan ketuntasan belajar dengan kriteria amat baik. Hal ini menunjukkan bahwa dalam menyusun dan mengukur kriteria ketuntasan belajar siswa, guruguru SD di UPTD Pendidikan Banyumanik sangat memperhatikan dan menggunakan informasi hasil penilaian dan evaluasi proses dan hasil belajar.

\section{Kemampuan Melakukan Tindakan Reflektif untuk Peningkatan Kualitas Pembelajaran}

Selain penilaian dan evaluasi hasil belajar, tindakan reflektif merupakan aspek penting sebagai umpan balik atau feedback dalam melakukan kegiatan pembelajaran.Berdasarkan analisis data, kemampuan guru-guru SD di UPTD Pendidikan Banyumanik Kota Semarang dalam melakukan tindakan reflektif untuk peningkatan kualitas pembelajaran dapat disajikan pada Tabel 10.

Tabel 10.KemampuanMelakukan Tindakan Reflektif untuk Peningkatan Kualitas Pembelajaran.

\begin{tabular}{|c|c|c|c|}
\hline No & Item Pernyataan & $\%$ & Kriteria \\
\hline 1 & $\begin{array}{lrr}\text { Melakukan } & \text { refleksi } & \text { terhadap } \\
\text { pembelajaran } & \text { yang } & \text { telah } \\
\text { dilaksanakan. } & & \\
& & \end{array}$ & 81.9 & Baik \\
\hline 2 & $\begin{array}{l}\text { Memanfaatkan hasil refleksi untuk } \\
\text { perbaikan dan pengembangan lima } \\
\text { mata pelajaran SD }\end{array}$ & 79.3 & Baik \\
\hline 3 & $\begin{array}{l}\text { Melakukan penelitian tindakan kelas } \\
\text { untuk meningkatkan kualitas } \\
\text { pembelajaran lima mata pelajaran } \\
\text { SD }\end{array}$ & 62.8 & Cukup Baik \\
\hline 4 & $\begin{array}{lrr}\text { Melakukan } & \text { refleksi } & \text { terhadap } \\
\text { pembelajaran } & \text { yang } & \text { telah } \\
\text { dilaksanakan. } & & \\
& & \end{array}$ & 81.9 & Baik \\
\hline & Total & 74.7 & Cukup Baik \\
\hline
\end{tabular}

Rerata skor kemampuan guru-guru SD di UPTD pendidikan Banyumanik Kota Semarang dalam melakukan tindakan reflektif 


$$
\text { recus }
$$

untuk peningkatan kualitas pembelajaran berada pada kriteria cukup baik. Rerata skor terendah terdapat pada item pernyataan melakukan penelitian tindakan kelas untuk meningkatkan kualitas pembelajaran lima mata pelajaran SD. Hal ini menunjukkan bahwa minat dan motivasi guru-guru SD di UPTD Pendidikan Banyumanik dalam melakukan penelitian tindakan kelas masih rendah. Oleh karenanya, penelitian tindakan kelas dirasa penting dilakukan oleh guru-guru sebagai tindakan reflektif untuk perbaikan pembelajaran. Adapun gambaran hasil analisis indikator kompetensi pedagogik guru Sekolah dasar di UPTD Pendidikan Banyumanik Kota Semarang dapat disajikan pada gambar 1 berikut:

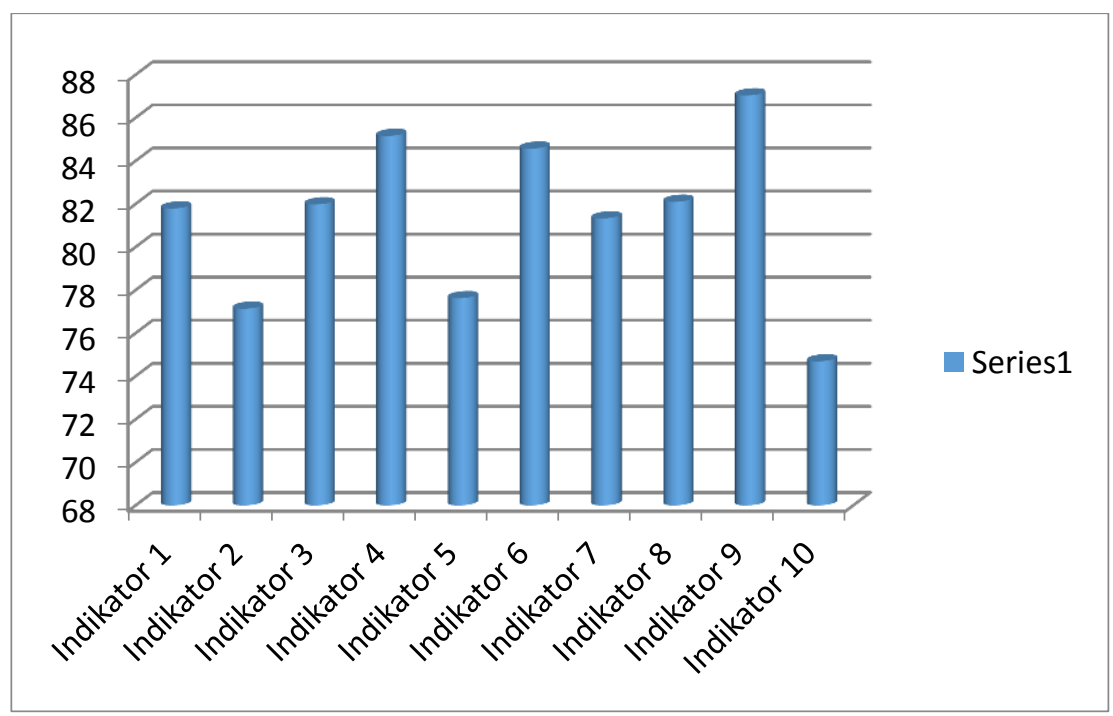

Gambar 1.Hasil Analisis Indikator Kompetensi Pedagogik Guru Sekolah Dasar di UPTD Pendidikan Banyumanik Kota Semarang

Secara umum, Kemampuan Pedagogik Guru Sekolah Dasar Pendidikan Banyumanik Kota Semarang berada pada kriteria baik dengan nilai sebesar 81.3\%.Berbicara mengenai kompetensi pedagogik sangat kompleks dan luas sebagimana ditegaskan oleh Liakopoulou, M. (2011: 474) bahwa untuk menentukan kriteria pengukuran atau penilaian kompetensi pedagogik dan memilih prosedur evaluasi sebuah profesi pendidikan, seseorang harus mampu menjawab pertanyaan misalnya kualifikasi dan kompetensi 


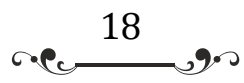

yang dibutuhkan untuk menjadi guru dan penilaian atau evaluasi.Secara rinci, Irina, A. \& Liliana (2011) menjelaskan bahwa kompetensi pedagogik sangat erat kaitannya dengan tiga fakor utama pendidikan yang mencakup efisiensi atau kesuksesan pendidikan, pengembangan profesional dan perubahan sosial. Pernyataan Andreia \& Liliana menunjukkan bahwa kompetensi pedagogik termasuk pengetahuan yang luas dan mapan, tipologi dan prinsip-prinsip pengembangan profesional yang dimiliki guru sangat menentukan kesuksesan mereka di masa depan yang dapat digunakan untuk mengembangkan proses berpikir kreatif dan kemampuan manajerial di berbagai bidang sehingga berdampak pada kualitas mengajar mereka di kelas. Senada dengan Andreia \& Liliana, Ticha, M. \& Hospesova, A. (2013) mendeskripsikan serangkaian kompetensi pedagogik yang berorientasi pada kemampuan mengontrol dan membangun hubungan serta kegiatan di kelas yang bertujuan untuk menciptakan lingkungan pendidikan yang efektif, supportif dan kondusif. Lebih dari itu, kemampuan berpikir kreatif dan kemampuan merencanakan pendidikan sepanjang hayat juga termasuk kompetensi pedagogik.

Hal senada mengenai kompetensi pedagogik secara spesifik ditekankan oleh Ramnarain, U. \& Schuster, D. (2014) bahwa agar berhasil mengajar di kelas, kompetensi pedagogik wajib dimiliki guru yakni mereka tidak cukup berbekal pengetahuan atau ilmu saja melainkan guru harus mampu menransfer ilmu dan pengetahuan kepada peserta didik melalui topik-topik tertentu. Pembelajaran yang baik yaitu pembelajaran yang mencakup dan mengajarkan nilainilai pembelajaran seperti aturan dan pelaksanaan pendidikan yang maksimal diantaranya menanamkan skill dan keterampilan pada siswa (Choo,S., 2012: 7).

Kompetensi pedagogik merupakan kemampuan guru Sekolah Dasar dalam pengelolaan pembelajaran peserta didik yang meliputi kemampuan menguasai karakteristik peserta didik, menguasai teori belajar dan prinsip-prinsip pembelajaran yang mendidik, mengembangkan kurikulum yang terkait dengan mata pelajaran yang diampu, menyelenggarakan pembelajaran yang mendidik, memanfaatkan teknologi informasi dan komunikasi untuk kepentingan pembelajaran, memfasilitasi pengembangan potensi 


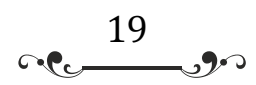

peserta didik untuk mengaktualisasikan berbagai potensi yang dimiliki, berkomunikasi secara efektif, empatik, dan santun dengan peserta didik, menyelenggarakan penilaian dan evaluasi proses dan hasil belajar, memanfaatkan hasil penilaian dan evaluasi untuk kepentingan pembelajaran, dan melakukan tindakan reflektif untuk peningkatan kualitas pembelajaran

\section{Simpulan}

Gambaran kompetensi pedagogik guru Sekolah dasar di UPTD Pendidikan Banyumanik Kota Semarang berada pada kriteria baik. Dengan demikian, guru Sekolah Dasar telah mampu menguasai karakteristik peserta didik dengan kriteria baik (81.8\%), menguasai teori belajar dan prinsip-prinsip pembelajaran yang mendidik dengan kriteria baik (77.1\%), mengembangkan kurikulum yang terkait dengan mata pelajaran/bidang pengembangan yang diampu dengan kriteria baik (82\%), menyelenggarakan pembelajaran yang mendidik dengan kriteria baik (85.2\%), memanfaatkan teknologi informasi dan komunikasi untuk kepentingan pembelajaran dengan kriteria baik (77.6\%), memfasilitasi pengembangan potensi peserta didik untuk mengaktualisasikan berbagai potensi yang dimiliki dengan kriteria baik (84.6\%), berkomunikasi secara efektif, empatik, dan santun dengan peserta didik dengan kriteria baik (87.8\%), menyelenggarakan penilaian proses dan hasil belajar dengan kriteria baik (82.1\%), memanfaatkan hasil penilaian untuk kepentingan pembelajaran dengan kriteria baik (87\%), melakukan tindakan reflektif untuk peningkatan kualitas pembelajaran dengan kriteria cukup baik (74.7\%). Oleh karena itu, guru-guru SD di UPTD Pendidikan Banyumanik Kota Semarang diharapkan mampu mengembangkan kompetensi pedagogik terutama melakukan tindakan reflektif sebagai upaya meningktakan kualitas pembelajaran. 


\section{reces 20}

\section{Daftar Pustaka}

Akhyak, dkk. 2013. Implementation of Teachers Pedagogy Competence to Optimizing Learners Development in Public Primary School in Indonesia. International Journal of Education and Research, 1 (9):110

Choo, S. S. 2012. Conceptualizing Literature Pedagogy: World, Global, and Cosmopolitan Orientations to Teaching Literature in English, Dissertation, Columbia University

Febrianis I, Muljono P, Susanto D. 2014. Pedagogical competence-based Training Needs Analysis for Natural Science Teachers. Journal of Education and Learning. 8 (2): 144-151

Gewasari, M. 2016. The Effect of Teacher Competence, Principal Pedagogical Leadership, School Spiritual Organizational Culture, Job Satisfaction of Teacher Development, Achievement Motivation toward Teacher Performance of Public Senior High School in Deli Serdang District. Journal of Humanities And Social Science.21(10): 29-38

Irina, A. \& Liliana. 2011. Pedagogical Competences - The Key to Efficient Education. International Online Journal of Educational Sciences, 3 (2): 411-423

Jaedun, A. 2009.Evaluasi kinerja profesional guru, makalah disampaikan pada pelatihan "refleksi profesi guru bersertifikat profesional, "di kantor Dinas Dikpora Kabupaten Cilacap.

Liakopoulou, M. 2011. Teachers' Pedagogical Competence as a Prerequisite for Entering the Profession.European Journal of Education, 46 (4): 474.

Nicholas, O.S.\& Boadu, K. 2013. Perception of Curriculum Innovation Needs For Pedagogical and Act Competencies among Education Students in University of Cape Coast, Ghana. International Journal of Humanities and Social Science. 3 (8) : 245-255

Olatunji, M. 0. 2013. Ensuring and promoting the pedagogical competence of university lecturers in africa. Journal of educational and instructional studiesIn the world. 3 (3):73-85

Ramnarain, U. \& Schuster, D. 2014. The Pedagogical Orientations of South African Physical 


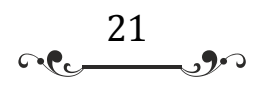

Sciences Teachers Towards Inquiry or Direct Instructional Approaches. Res Sci Educ .44: 630.

Sugiyono. 2016. Statistika untuk Penelitian. Bandung: AlfabetaSukmadinata, N. S. 2013. Metode Penelitian Pendidikan. Bandung: Rosdakarya.

Surapranata, S. 2016. 7 Provinsi Raih Nilai Terbaik Uji Kompetensi Guru 2015. Available at: https://www.kemdikbud.go.id/main/2016/01/7provinsi-raih-nilai-terbaik-uji-kompetensi -guru-2015, diakses pada tanggal 20 Maret 2018

Suryawati, E. \& dkk. 2014. Analisis Keterampilan Technological Pedagogical Content Knowledge (TPCK) Guru Biologi SMA Negeri Kota Pekanbaru Jurnal Biogenesis, 11(1):68-72

Ticha, M. \& Hospesova, A. 2013.Developing teachers' subject didactic competence through problem posing.Educ Stud Math. 83: 133-143

Undang-undang Republik Indonesia No. 14 tahun 2005 tentang Guru dan Dosen

Yaumi, M. 2011. Integrasi Teknologi Informasi dan Komunikasi dalam Pembelajaran.Lentera Pendidikan. 1 (14): 88-102.

Zakaria, T. 2017. Pembenahan Mutu Guru, Buletin BSNP, Vol. XI/ No. 3. Diakses tanggal 15 Januari 2018 